\title{
EAMR
}

European Accounting and

Management Review

EUROPEAN ACCOUNTING AND MANAGEMENT REVIEW · VOL. 2, NO. 2, 1-19 MAY 2016

\section{Use of accounting in company collective agreements. Proposal for a new salary review model in the context of corporate social responsibility and stackeholder theory}

\author{
Pablo Aguilar Conde \\ Universidad de Burgos \\ Begoña Prieto Moreno \\ Universidad de Burgos \\ Alicia Santidrián Arroyo \\ Universidad de Burgos
}

Received March 26, 2016; accepted May 27, 2016.

\begin{abstract}
Our purpose here is to analyze how salary reviews are established in Collective Bargaining Agreements, while arguing the case for a new salary review model that reinforces the link between wage-setting mechanisms and changes in productivity. The thinking behind Spanish labour and mercantile legislation promotes changes to salary review methods in Collective Bargaining Agreements, based on both agency and stakeholder theory.

Our proposal for a new model will join the interests of directors and those of other employees. The rewards produced by the work of each group will be based on the business value generated by all internal stakeholders of the company: shareholders, directors and employees.

Labour relations are certainly moving towards a scenario that makes it desirable to achieve common goals, in which companies can distribute their benefits to all of their stakeholders: principally shareholders, directors, and employees, as we propose in this paper.
\end{abstract}

\section{KEYWORDS}

Collective business agreement, stakeholders, corporate social responsibility, business profits, accounting information. 


\section{Introduction}

The initial purpose of this paper in its first phase is to analyze how salary reviews and variable levels of compensation in Collective Bargaining Agreements (CBAs) are established in companies. We analyzed more than 350 CBAs between 2002 and 2015. We draw our main conclusions from the descriptive analysis and we describe the trend that, from our point of view, has been changing over recent years.

The reality we observe appears to show evidence that a drop in purchasing power due to inflation may be recovered by establishing automatic clauses for wage adjustments negotiated in collective agreements in line with the inflation rate-Consumer Price Index (CPI). However, the economic crisis at the end of 2007 was a turning point that has had an important effect on wage reviews.

If we consider that workers are partners or stakeholders in a company, then it would be advisable to link the wage review to the economic situation of the company, pegging specific wages to the financial performance of the company on the basis of its economic data; especially under the present circumstances with zero or negative inflation.

In a second phase, we administered surveys to human resources managers. First of all, to managers in companies located in Burgos and then, in 2015, to human resources managers who were members of the human resources managers network in Castilla-León. Our main goal is to gain an overview of standard wage review clauses in collective enterprise agreements and the possibilities of their modification. The findings of these surveys are discussed in a third phase with the most representative associations and trades unions in Burgos. In these interviews, we try to validate feedback from the employees. Finally, we will propose a new model of collective bargaining, which ties worker remuneration to the economic situation of each company, implying greater engagement, which can result in higher productivity and better business results.

In our opinion, this approach could be adopted in mandatory financial information from companies, particularly within the notes to the accounts of their financial statements. With this additional information, every user of accounting information will have accurate information on the distribution of company profits to shareholders, directors, and workers. This information could be mentioned alongside information on employees and directors, in the annual reports.

Following this approach, we will briefly outline the structure of this paper. The first section will present the basic premises, observance of which we consider is important; 
these are taken from agency theory between employer and employees. In the second section, we will situate the employment contract within the legal framework of labour law, by analyzing the safeguards for this employment contract in positive law, while paying special attention to collective bargaining regulations and rules for directors in company law. The third section will present a brief review of the empirical use of accounting information in collective bargaining. In the fourth section, we will describe the data sources (collective agreements, interviews, and surveys) and the method used for their analysis and, in the fifth section, the empirical analysis and its results. Finally, in the sixth section, we will list the essential results from our data observation and summarize the main conclusions that lead us to suggest a new salary review model, in the context of collective bargaining that can improve negotiation processes and lead to better outcomes. 


\section{Conceptual framework}

The theoretical foundations of this paper are based on the perspective of new institutional economics. In this framework, the company is a complex organization operating under uncertain conditions and with limited information, where the absence of perfect information causes problems.

In reference to the nexus of contracts that exist in the firm, we wish to explore the employment contract, conditional upon asymmetric information, uncertainty, limited rationality and opportunism; where the employer-employee relationship can be described as incomplete, bilateral and authoritatively overbearing.

In this way, agency theory is a useful framework for analyzing the contractual process in the company. An agency relationship is, in general terms, the relationship between two parties, where one is a principal and the other is an agent who represents the principal in transactions with a third party. Agency relationships arise when the principal hires the agent to perform a service on behalf of the principal. Principals commonly delegate decision-making authority to the agents. The employment relationship is one in which the employee agrees to work for a wage, which may or may not be based on various indicators of productivity, working and yielding results for the employer.

Firms incur costs in the coordination of highly interdependent tasks which imply collecting, processing, and transmitting copious information, from top management to information users. The costs of negotiating a contract are transaction costs associated with the negotiations between the parties in the process; including the time and resources spent on both trading and improving the negotiating position, as well as losses incurred by failure or delay in reaching an efficient agreement. In addition, firms also incur costs when monitoring and encouraging workers who have been delegated decision-making authority: agency costs. Among these costs, we can mention the costs prior to contract signing and formalization: formalization and warranty costs; and costs applicable after signature or negotiation: monitoring costs and residual losses. In general, these are the costs of a contractual relationship, in order to mitigate conflict between the parties and to reduce the risk of default. They cover negotiation costs and contract finalization and labour agreement costs; including coordination costs, incentivization costs, and the costs of setting performance measures, to create incentives and to track agreements to ensure that employees follow instructions, fulfill their commitments and keep to agreements.

Accounting information can help to solve one of the organizational problems discussed by Jensen and Meckling (1995): the control system in its dual role, performance 
evaluation and reward methods. We need to develop a control system that is consistent with the allocation of decision rights. This control system would consist of the performance measurement and reward system, to align the interests of employees with those of employers.

Therefore, a control system of this sort to overcome organizational problems in the design of mechanisms that allocate decision rights would focus on measuring and rewarding performance. The accounting information system can serve as a mechanism for information and control, reducing informational asymmetries (prior-contractual costs) and opportunistic behaviors subsequent to contract completion (post-contractual costs). Specifically, our proposal is that accounting information be used as a mechanism that promotes performance appraisal of both workers and directors alike and that maintains suitable methods for remuneration within the company. (Table 1) 


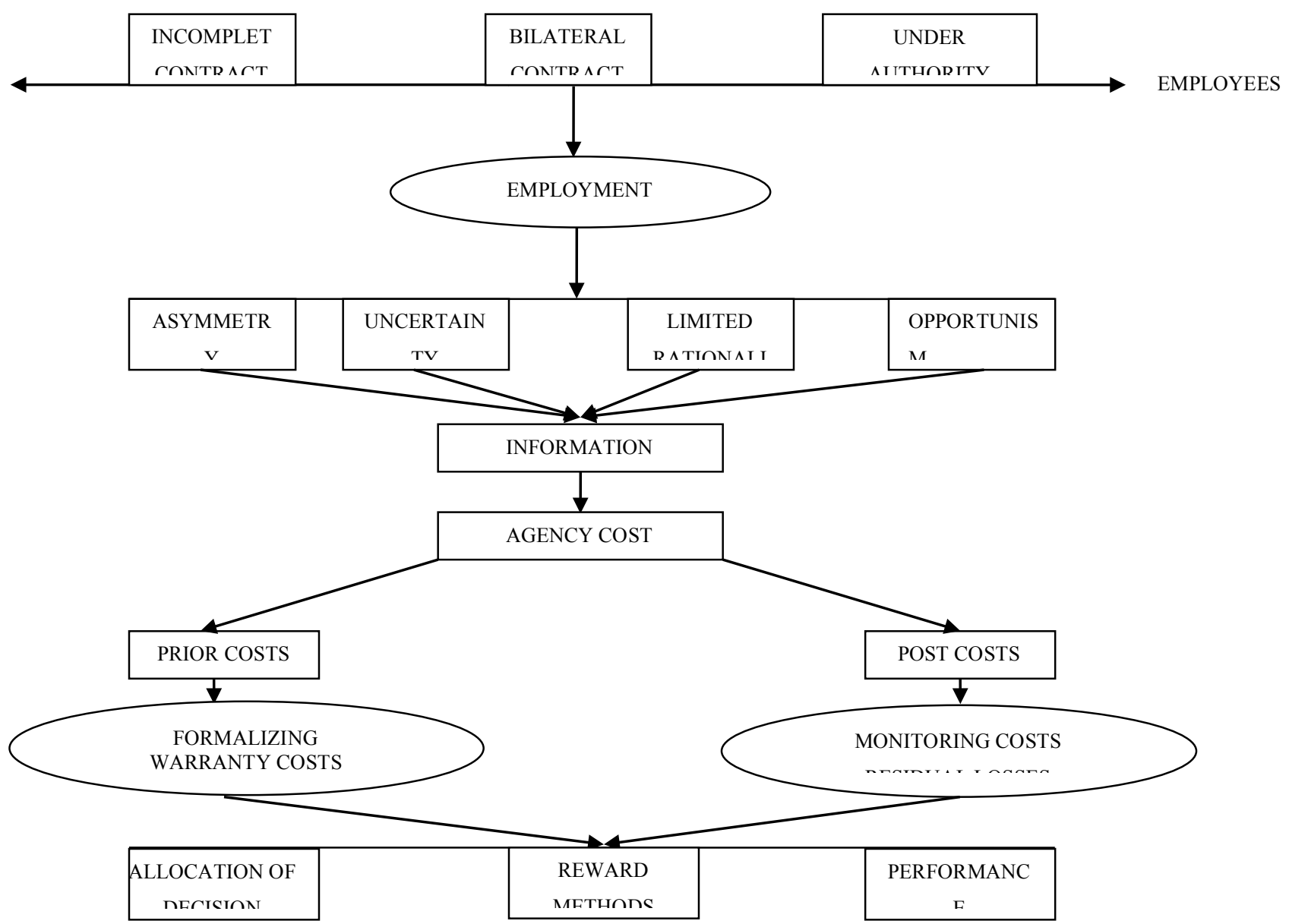

Source: Authors, based on agency theory

Table 1. Theoretical Model

\section{Legal framework}

The references to the use of accounting information are expressly set out in the Statutes of Workers, in which a brief mention may be made of the following:

Article 26: ... The salary shall, among other factors, be determined by the situation and the results of the company...

Article 47: An employment contract may be suspended... for economic reasons... Economic reasons can be argued when the results of the company and a negative economic situation can be proven. The existence of actual or planned losses are reasonable economic causes when there is a persistent decrease in the level of revenue or sales. In any case, it is understood that the decrease is persistent, if over two consecutive quarters, the level of revenue or sales for each quarter is lower than in the same quarter of the preceding year... 
Article 51: Collective dismissals, with a similar text as in article 47, refer to the concurrence of economic causes.

Article 64: A council shall have the following rights: to be informed of the balance sheet, profit and loss account, annual report and, if the company is a corporation based on shares or participations, of any other documents provided to the members, under the same conditions...

Article 82.3: ... A Collective Bargaining Agreement shall establish the conditions and procedures that may exclude the application of the salary system in force to companies in a weak financial situation, both in the collective agreement of the firm or the industry, ... Additionally, we wish to compare company regulations on the compensation for employees and directors, and we should therefore underline the following sections of the Corporate Enterprise Act, where the remuneration system for directors is expressly stated:

Article 217.2: The remuneration system established for directors may include, among others, one or more of the following items:
a) fixed salary;
b) attendance fees;
c) profit sharing;
d) variable performance payments on the basis of defined indicators or benchmarks;
e) exceptional payments in the form of company shares or linked to their performance;

Article 217.4: The remuneration of directors should be reasonable in proportion to the size of the firm, the economic situation and in line with standard market references. The remuneration system that is established should be set within the framework of long-term profits, including sustainability and reasonable precautions to avoid excessive risk and reward, in case of unfavorable results.

Article 218.2: In limited liability companies, when remuneration is based on profit sharing, the company or industrial regulations shall specify their maximum levels or percentages, which may under no circumstances exceed ten per cent of the profits set aside for distribution among partners. 
Article 218.3: 2: In joint-stock companies, when remuneration consists of profit sharing, it may only be drawn from net earnings after making provision for legal reserves and any other reserve described in the regulations and after allocating a four-per cent dividend (or higher if provided in the regulations) for shareholders.

In short, we think that under stakeholder theory, in which both directors and workers are internal stakeholders of the company, remuneration via profit sharing should be considered both for employees (Statute of Workers) and for directors (Company Law), using references linked to productivity and business performance.

It is unfair to speak of corporate social responsibility relating to working conditions, if one of the main demands from workers is a fair wage, and their salaries have been frozen and are unlikely to be reviewed, unlike the remuneration of other stakeholders in the company. Directors may have increased their remuneration, partners and shareholders may have received dividends, on the back of employee contributions to business performance. It therefore appears fair that employees should benefit from salary reviews in the same way as directors and shareholders.

As we pointed out in the theoretical framework, if added value is generated that may be measured by a performance ratio, it seems obvious that the remuneration for this performance and the distribution of this added value should take into account all stakeholders and, obviously, all employees.

\section{State of the art}

A seminal study on this subject, titled "The use of financial information in collective bargaining” led to the paper from Pillsbury “Organized labor's view of corporate financial information" published in 1958. The development of these studies reached its peak in 1980-1990.

Geographically, important contributions have appeared in every continent and especially in German, Great Britain, Japan, Scandinavian countries, South Africa, and the United States, etc. In Spain, the few studies that may be underlined are those of Pons (1996), Laffarga (1993) and Sabater (2011).

Some references in this respect are underlined in table 2: 


\begin{tabular}{|c|c|c|c|}
\hline AUTHOR & OBJECTIVES & SAMPLE & RESULTS \\
\hline $\begin{array}{l}\text { Horwitz and } \\
\text { Shabahang } \\
\text { (1971) }\end{array}$ & $\begin{array}{l}\text { Study of the } \\
\text { relationship between } \\
\text { financial statements } \\
\text { and wage rises }\end{array}$ & $\begin{array}{l}15 \text { companies } \\
\text { with CBA in } \\
1945-1967\end{array}$ & $\begin{array}{l}\text { The only representative } \\
\text { variables are margins and } \\
\text { dividends }\end{array}$ \\
\hline $\begin{array}{l}\text { Foley and } \\
\text { Maunders } \\
(1971)\end{array}$ & $\begin{array}{l}\text { The same as in } \\
\text { Hortwitz and } \\
\text { Shabahang (1971) }\end{array}$ & $\begin{array}{l}117 \text { companies } \\
\text { with CBA in } \\
\text { 1971-1972 }\end{array}$ & $\begin{array}{l}\text { The only representative } \\
\text { variables are turnover, earnings } \\
\text { per share, and solvency. }\end{array}$ \\
\hline $\begin{array}{l}\text { Peel and Pope } \\
\text { (1984) }\end{array}$ & $\begin{array}{l}\text { Study of different } \\
\text { wages by accounting } \\
\text { and financial } \\
\text { variables }\end{array}$ & $\begin{array}{l}95 \text { companies in } \\
1977-1980\end{array}$ & $\begin{array}{l}\text { Any accounting variable is } \\
\text { significant. Only the irregular } \\
\text { return (real return - planned } \\
\text { return) is significant }\end{array}$ \\
\hline
\end{tabular}

Source: Authors, compilation based on the literature review

Table 2. Some empirical contributions

\section{Data sources and methodology}

This information was obtained over two different periods: during the period 2002-2014, for all companies with a workplace in the province of Burgos, registered with the territorial authorities of Castilla-León in Burgos; and from January to December 2015, for all companies in Castilla-León with provincial CBAs.

All the existing data sources were consulted to explore the available accounting information and to explain its application to an alternative model of remuneration in company collective bargaining:

- 303 collective agreements from 69 companies in Burgos between 2002 and 2014. 58 collective agreements from 58 companies in all provinces of Castilla-León, between January and December 2015.

- Surveys sent in 2001 to human resources managers of companies in Burgos who have signed collective agreements. Surveys sent in 2015 to human resources managers of different companies of Castilla-Leon, forming part of the network of human resources managers of Castilla-Leon (CEDERED). 
- Interviews administered in 2015 to the three most representative trade unions in the province of Burgos.

Firstly, a descriptive analysis of all CBAs over the period 2002-2014 and 2015 was prepared; to pinpoint the key data, comparative information and trends.

In second place, a multivariate analysis of the information collected through questionnaires to human resources managers was conducted, to measure associations within the questions from the questionnaire. This analysis was developed in two stages with the data-processing program SPAD version 5.5. In the first stage, considering the qualitative nature of the questionnaire data, a multiple correspondence analysis was performed. As we found no clear association between them, only one of the most important questions in the survey was selected, but no other relationship was found between them. In the second stage, we (unsuccessfully) attempted a classification through cluster analysis to find a type of company according to the surveys and their CBAs, specifically the inflation rate or variable wage review

Finally, interviews were conducted with the most representative trades unions, in order to collect the perceptions of workers from the standpoint of human resources managers.

\section{Analysis of results}

From the detailed analysis of the different sources of data, the following results may be highlighted:

- From collective agreements for the period 2002-2014, only 10 out of 69 companies (less than 15\%) proposed a variable wage review in relation to the results in most cases.

On the basis of CBAs over the period 2002-2014, 17 out of 69 companies used some form of variable remuneration considering basic internal accounting data.

- In new collective agreements signed from January to December 2015 relating to companies in Castilla-León, 14 out of 58 companies referred to external accounting information to establish the financial participation of workers; that is, a quarter of all companies. 
Moreover, in a quarter of these companies, reference to internal accounting and productivity was in most cases considered.

- From the survey administered to human resources managers in 2001, we can conclude that most companies considered the CPI when setting the wage increase, despite the importance of accounting information for collective bargaining.

However, only one company considered that the accounting data was the most important to establish ordinary wages; but half of the companies considered the accounting information more important than the CPI to establish the increase in variable compensation. The most important reference was the profit line, more than other data such as turnover or solvency.

Finally, almost half of companies believed that the workers would moderate their wage demands if they had accounting information. Although all companies believed that if they had higher profits, the wage demands of workers would increase were the workers to have this accounting information.

In spite of the interest in accounting information for the negotiation of CBAs, only a quarter of the companies were willing to negotiate with accounting data without considering the CPI.

- From the survey in 2015 administered to the human resources managers of companies in Castilla-León, we can conclude that human resources managers considered particular company aspects more than general economic elements (perhaps because of the effect of the crisis in companies), as the most important factors for the negotiation of CBAs. So, the most valuable reference for human resources managers to set the salary review was the economic information of the company and not the CPI.

Accounting information, according to human resources managers, is not given sufficient consideration by union representatives to change their negotiating positions; $60 \%$ of them expressed that opinion, while a very similar number acknowledged that they made no use of it at all. At a further stage, that is discussed later on, interviews with the most representative unions were conducted, in order to underline the existence of asymmetric information and lack of trust between the parties. 
Despite the previous responses, $77.50 \%$ considered that the situation and the results of the company would be accepted to set wage increases and variable remuneration, which demonstrates a preference for the accounting information, as we anticipated in our theoretical proposal.

In Spanish Labour Law, negative economic situations may be a reason not to apply CBAs. Human resources managers were asked whether, in an upbeat economic situation, they would welcome labour law that included the workers as beneficiaries of that situation. Only half of them considered this proposal. From the point of view of our theoretical approach, rejection of this proposal hardly appears reasonable; if variable levels of compensation are considered, then it would appear advisable to do so under any economic situation. It is really very difficult to defend a balanced position when this view is unacceptable human resources managers.

There is definitely no absolute consensus among human resources managers over the involvement of workers in an upbeat economic situation by giving them access to the economic data of the company.

- The unions showed no agreement with the responses from human resources managers. They maintain that the most acceptable reference for wage reviews is an increase in the CPI, because they do not believe that the accounting situation of the company reflects the real situation of each company, especially when corporate groups move results from one company and one country to another. So the increase in the CPI would bolster wage demands when the upbeat economic situation of the company can allow it.

However, it is important to underline the commitment of unions to productivity, undoubtedly because over recent years, workers have felt that productivity can maintain employment, and their efforts are rewarded when company results improve.

But above all, were accounting information reliable, then they would accept this reference as long as the positive situation may be considered to establish extra wage increases, rather than the use of only economic stagnation or depression to justify wage constraints. 


\section{Conclusions}

The following conclusions may be emphasized on the basis of the empirical analysis: As shown in section 5, the number of companies using financial references for wage reviews has increased, from 10 companies in the period 2002-2014 to 14 companies in 2015. In fact, 4 out of the 8 companies in Burgos that signed CBAs in 2015 have established financial references for their salary reviews, while in previous agreements they only referred to CPI. This changes the current trend: only $20 \%$ of companies use the CPI strictly as a reference for their salary review processes.

The number of companies using financial references for variable remunerations also increased: from $15 \%$ in the period from 2002 to 2014 to $25 \%$ of all companies in 2015 . As we have previously suggested: there is an absolute divergence of interests. Companies wish to use financial references with negative economic circumstances; however, this behavior was not observed in upbeat economic situations. The workers themselves would be prepared to extend the financial references for wage review, despite their doubts over the authenticity of economic information from the company, if positive circumstances were also considered to recognize their share in company profits.

In short, as the title of the paper proposes, it appears advisable to move towards a new model of collective bargaining that takes into account the economic circumstances of each company, and involves employees in achieving business goals.

We propose a new model based on the following points (Table 3):

- If the company does not increase its sales and/or profitability compared to the average data from the sector, then the salary review could at least ensure changes in line with the CPI.

- If the company decreases its turnover and/or profitability, the salary review could freeze wages or even agree on a wage cut as already planned in the Statutes of the Workers.

- If the company improves its sales and/or profitability, we propose that workers should participate in a percentage of corporate earnings. 


\begin{tabular}{|c|c|c|c|c|}
\hline \multicolumn{5}{|c|}{ COMPANY TURNOVER } \\
\hline \multirow{3}{*}{ RETURN } & & Lower & Equal & Higher \\
\cline { 2 - 5 } & Lower & Wage cuts & Maintain & + CPI \\
\cline { 2 - 5 } & Equal & Maintain & + CPI & Participate \\
\cline { 2 - 5 } & Higher & Maintain & + CPI & Participate \\
\hline
\end{tabular}

Source: Author's own preparation

Table 3. Proposal of new model

It would also be appropriate to establish productivity references in collective agreements at an industrial level, so that this reference could be automatically used in CBAs. This situation and our previously proposed model could concentrate efforts on other tasks such as improving productivity and attempting to find a solution to the high rate of unemployment in Spain.

Another desirable advance would be to replace or to complement the fixed salary with variable participation in company profits, apart from the salary review. The evidence shows that salary reviews with reference to financial information is not very important; we should promote a link between company results and salaries, seeking significant incentives for employee motivation.

Following the recommendations on corporate governance of December 2014, it was established in Spanish Company Law in January 2015 that remuneration for directors should be reasonable, proportional with the size of the company, the economic situation and comparable with standard market references. The compensation system that is established should be oriented towards a long-term profit view, including sustainability and should take reasonable precautions to avoid excessive risk and reward in case of unfavorable results. (Article 217)

Additionally, we consider it important that company reports include the distribution of the net result among their internal stakeholders: shareholders, directors and employees; foreseeing this information as a mandatory statement for inclusion in the annual reports of companies, as proposed in table 4.

\begin{tabular}{|c|c|c|c|}
\hline \multicolumn{4}{|c|}{ PROFIT SHARING } \\
\hline \multirow{4}{*}{$\begin{array}{c}\text { INTERNAL } \\
\text { STAKEHOLDERS }\end{array}$} & & $\mathrm{Yes} / \mathrm{No}$ & Percentage \\
\hline & Shareholders & & \\
\hline & Directors & & \\
\hline & Employees & & \\
\hline
\end{tabular}

Source: Author's own preparation

Table 4. Proposal of new information to include in the notes to the financial statements 
This paper refers to CBAs, where companies are active in a provincial local area, both in Burgos for the first period of analysis and in all provinces of Castilla-León for 2015; which means that companies from different sectors and sizes have been analyzed. However, this is one of the main limitations, that could be overcome in future research, as the companies under analysis have work centers in more than one place in CastillaLeón. Moreover, company collective agreements are not annually published and most of them exceed one year; this situation means that wage variations may not be properly studied when the economic situations are unknown at the time of signing the CBA.

All the previous limitations also justify the possibility of extending this work further. This paper may be seen as an encouragement to continue covering further stages in the study of accounting information on industrial relations.

The following avenues for future research may be underlined:

- An analysis in listed companies of trading behavior with different ways of setting wage variations and the application of accounting references.

- Intensify a cause-and-effect analysis through the case study of a company that has switched from not using accounting information in collective bargaining to using it.

- A study of the effect of economic and financial remuneration according to financial statements with the strategic change of companies and productivity, competitiveness and profitability, paying special attention to the link between the reward system and company results.

- An analysis of management tools, such as the balanced scorecard, to encourage better levels of performance linked to variable remuneration from workers. The balance scorecard should be planned as a mechanism to motivate workers, who have to achieve certain daily operational goals, that have an effect on their variable remuneration and allow them to achieve their strategic objectives within the organization. The measure of learning and growth prospects as well as internal processes, (times productivity indicators, quality-ratios, training, innovation, suggestions, safety, flexibility, etc.) would allow the company to obtain more accurate and reliable information. 
We would also like to point to another future line of work: the relationship between compensation and the degree of corporate social responsibility of companies. Can a company be responsible without ensuring participatory payments to workers? In the $31^{\text {st }}$ Workshop on Strategic Human Resource Management, organized by the European Institute for the Study of Business Administration (EIASM), held in Segovia in April 2016, the possibility of extending a degree of social responsibility to employees was discussed; as well as the possibility of studying whether they would be in favour of foregoing or replacing part of their salary, if that part were to be allocated to some measure that would increase the level of their corporate social. If that were to happen, it would confirm our approach of cooperation and participation between employers and employees.

So, in conclusion, every internal stakeholder of the company should be involved in achieving business goals, not only profit but company value and appropriate distributions of this value among the participants in the company. The approach proposed here suggests that this involvement should be taken into consideration by the company: fair distribution of dividends to shareholders, sufficient compensation for directors and fair wages for workers. Only when that complicity among stakeholders is found, will the survival of the company and its corporate social responsibility be guaranteed. 


\section{REFERENCES}

Alchian, A. \& Demsetz, H. (1972) "Production, information costs, and economic organization". The American Economic Review. December. pp 777-ARRUÑADA, B. "La empresa como nexo contractual". Libro de Economía de la empresa: un enfoque contractual. Chapter 3. pp 65-84.

Azofra Palenzuela, V. \& Miguel Hidalgo, A. DE (1992) "Teoría financiera de la agencia, endeudamiento \& estructura de propiedad". Revista Europea de Dirección y Economía de la Empresa. Vol 1. n² 2. pp 135-146.

Brickley, J.; Smith, C. \& Zimmerman, J. (1995) "The economics of organizational architecture". Journal of Applied Corporate Finance. Vol 8. n². Summer 1995. pp 1931.

Brousseau, E. \& Glachant, J.M. (2000) "Economie des contrats el renouvellements de l'analyse économique". Revue d'Économie Industrielle $\mathrm{n}^{\circ} 92,2^{\circ}$ et 3 trimestre 2000. pp 23-50.

Burchell, S.; Clubb, C.; Hopwood, A. \& Naphapiet, J. (1980) "The roles of accounting in organizations and society". Accounting, Organizations and Society. vol 5. n¹. 1980. pp $5-27$

Charreaux, G. (2000) "La theorie positive de l'agence: positionnement et apports". Revue $d^{\prime}$ Économie Industrielle $\mathrm{n}^{\circ} 92,2^{\circ}$ et 3 trimestre 2000. pp 193-214.

Coase, R. (1937) “The nature of the firm”. Económica, 4. pp 386-405.

Elias, N. (1990) "The effects of financial information symmetry on conflict of labor negotiations". The Accounting Review. Vol. 65. no 3. July 1990. pp 606-623.

Fama, E. (1980) "Agency problems and the theory of the firm". Journal of Political Economy, 88. pp 288-307.

Foley, B. J. \& Maunders, K.T. (1977) "Accounting information disclosure and collective bargaining". New York; Holmer and Meier Publishers.

Hassink, H. (1995) "An empirical exploration of the role of financial accounting information and of auditors in collective bargaining". Paper presented at the 18th annual congress of the European Accounting Asociation. Birmingham. United Kingdom. May 1995.

Horwitz, B. \& Shabahang, R. (1971) "Published corporate accounting data and general wage increases of the firm". The Accounting Review. Vol. XLVI. $\mathrm{n}^{\circ}$ 2. April 1971. pp 243-252.

Jensen, M. \& Meckling, W. (1976) "Theory of the firm: managerial behavior, agency costs, and ownership structure”. The Journal of Financial Economics, 3. pp 305-360. 
Jensen, M. \& Meckling, W. (1995). "Specific and general knowledge, and organizational estructure". Journal of Applied Corporate Finance. Vol 8. n 2. 1995. pp 4-18.

Laffarga Briones, J. (1993) "Información contable y negociación colectiva". Trabajo de Investigación. Universidad de Cádiz.

Ley $31 / 2014$, de 3 de diciembre, por la que se modifica la Ley de Sociedades de Capital para la mejora del gobierno corporativo [Law 31/2014, of 3 of December, in modification of the Law of Capital Companies for the improvement of corporate governance.]

Liberty, S. \& Zimmerman, J. (1986) "Labor union contract negotiations and accounting choices". The Accounting Review. Vol. LXI. no 4. 1986. pp 692-712.

Morishima, M. (1991) "Information sharing and collective bargaining in Japan: effects on wage negotiations". Industrial and Labor Relations Review. Vol. 44. n 3. Abril. pp 469-485.

Ogden, S. \& Bougen, P. (1985) "A radical perspective on the disclosure of accounting information to trade unions". Accounting, Organizations and Society. Vol. 10. №2. 1985. pp 211-224.

Peel, D.A. \& Pope, P.F. (1984) "Corporate accounting data, capital market information and wage increases of the firm". Journal of Business Finance \& Accounting. 11. 2. Summer 1984. pp 177-188.

Pillsbury, W.F. (1958) “Organized labor's view of corporate financial information”. Journal of Accountancy. June. pp 46-56.

Pons Felix, A. (1996) “Información y relaciones laborales”. Técnica contable. pp 59-68.

Real Decreto Legislativo 1/2010, de 2 de julio, por el que se aprueba el texto refundido de la Ley de Sociedades de Capital. [Royal Legislative Decree 1/2010, of 2 July, in approval of the amended version of the Law of Capital Companies].

Real Decreto Legislativo 2/2015, de 23 de octubre, por el que se aprueba el texto refundido de la Ley del Estatuto de los Trabajadores. [Royal Legislative Decree 1/2015, of 23 Octover, in approval of the amended version of the Law for the Statute of Workers].

Ross, S. A. (1973) "The economic theory of agency: the principal's problem". American Economic Review. Vol 63 n² 2. 1973. pp 134-139.

Sabater Marcos, Ana M. (2005) "Efecto de la negociación colectiva en el mercado continuo español: un análisis empírico". Revista Española de Financiación y Contabilidad. Volumen XXXIV, n 126 . pp 787-790.

Sabater Marcos, Ana M. \& Laffarga Briones, J. (2006) “¿Observa el mercado español las relaciones laborales ente empresarios y sindicatos? Un análisis empírico para el mercado continuo". Revista española de financiación y contabilidad, Vol. XXXV, $\mathrm{n}^{\mathrm{o}} 128$. pp 5786. 
Sabater Marcos, Ana M. \& Laffarga Briones, J. (2008) "Información estratégica en la negociación colectiva: evidencia empírica para el mercado continuo español”. Revista española de financiación y contabilidad, Vol. XXXVII, nº 138. pp 315-352.

Sabater Marcos, Ana M. \& Laffarga Briones, J. (2008) "Spillover effect upon a labor event: an empirical analysis for the Spanish continuous market". Revista española de financiación y contabilidad, Vol. XXXVII, nº 140. pp 633-664

Sabater Marcos, Ana M. \& Laffarga Briones, J. (2011) "An empirical analysis of labour agreements on Spanish Stock Market". Investment Management and Financial Innovations, Volume 8, Issue 2. pp 26-38.

Simon, H. (1951) "A formal theory of the employments relationship". Econometrica. Vol 19. pp 293-305.

Watts, R. \& Zimmerman, J. (1983) "Agency problems, auditing, and the theory of the firm: some evidence". Journal of Law and Economics. Vol XXVI. Octubre 1983. pp 613633.

Watts, R. \& Zimmerman, J. (1990). "Positive acounting theory: a ten year perspective". The Accounting Review. Vol 65. n¹. 1990. pp 131-156.

Williamson, Oliver E. (1990), “A Comparison of Alternative Approaches to Economic Organization” Journal of Institutional and Theoretical Economics. Vol 146. pp 61-71. 